\title{
Mesoscale surface distribution of biogeochemical characteristics in the Crozet Basin frontal zones (South Indian Ocean)
}

\author{
M. Fiala ${ }^{1, *}$, B. Delille ${ }^{2}$, C. Dubreuil ${ }^{3}$, E. Kopczynska ${ }^{4}$, K. Leblanc ${ }^{3}$, J. Morvan ${ }^{5}$, \\ B. Quéguiner ${ }^{3}$, S. Blain ${ }^{6}$, C. Cailliau ${ }^{6}$, P. Conan ${ }^{1}$, R. Corvaisier ${ }^{6}$, M. Denis ${ }^{3}$, \\ M. Frankignoulle ${ }^{2}$, L. Oriol ${ }^{1}$, S. Roy ${ }^{3}$ \\ ${ }^{1}$ Laboratoire Arago, Université P \& M Curie, UMR-CNRS 7621, 66651 Banyuls-sur-mer Cedex, France \\ ${ }^{2}$ Unité d'Océanographie Chimique, Institut de Physique, Université de Liège, 4000 Sart Tilman, Belgium \\ ${ }^{3}$ Laboratoire d'Océanographie et de Biogéochimie, Université de la Méditerranée, UMR-CNRS 6535, Parc Scientifique et \\ Technologique de Luminy, Case 901, 13288 Marseille Cedex 9, France \\ ${ }^{4}$ Department of Antarctic Biology, Polish Academy of Sciences, Ustrzycka 10, 02141 Warszawa, Poland \\ ${ }^{5}$ Ecole Normale Supérieure de Chimie de Rennes, Avenue du Général Leclerc, 35700 Rennes-Beaulieu, France \\ ${ }^{6}$ Laboratoire des Sciences de l'Environnement Marin, Institut Universitaire Européen de la Mer, Université de Bretagne \\ Occidentale, UMR-CNRS 6539, 29280 Plouzané, France
}

\begin{abstract}
A mesoscale study was conducted in January and February 1999 in the Crozet Basin frontal zones $\left(43^{\circ} 50^{\prime}\right.$ to $45^{\circ} 20^{\prime} \mathrm{S}, 61^{\circ} 00^{\prime}$ to $\left.64^{\circ} 30^{\prime} \mathrm{E}\right)$ within the southernmost and easternmost convergence area of the Antarctic Circumpolar Current (ACC) and the Agulhas Return Current (ARC). Distribution of biogeochemical parameters was strongly linked to the merged Subtropical (STF) and Subantarctic (SAF) Fronts which mark the border between the cold and less saline subantarctic waters and the warm and more saline subtropical waters. This survey took place during a post-bloom period. Chlorophyll a concentrations were low throughout the study area ranging from $0.2 \mu \mathrm{g}^{-1}$ in the Polar Frontal Zone (PFZ) to $0.4 \mu \mathrm{g} \mathrm{l}^{-1}$ in the Subtropical Zone (STZ). Maximum chlorophyll a values $\left(0.8 \mu \mathrm{g} \mathrm{l}^{-1}\right)$ associated with an increase in biogenic silica concentration (from 0.03 to $0.34 \mu \mathrm{M}$ ) and

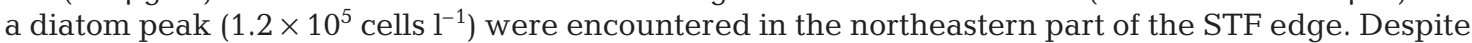
northwardly decreasing concentrations of nitrates from $14 \mu \mathrm{M}$ in the PFZ to $6 \mu \mathrm{M}$ in the STZ, they were not the main factor limiting phytoplankton growth. Low silicic acid (mean $=0.6 \mu M)$ could have limited diatom development in the PFZ and the STZ where diatom numbers were low. In STZ waters, where average diatom numbers were highest, various species of Nitzschia and Thalassiothrix were common, but Pseudonitzschia spp. were dominant. Throughout the survey area, pico- and nano-sized cells dominated the phytoplankton assemblage, and their number was the highest in the STZ. Cyanobacteria, only present in subtropical waters $>12.5^{\circ} \mathrm{C}$, were the major component of the picoplankton size-fraction. While dinoflagellate numbers were low in the Subantarctic Zone (SAZ), their abundance and species numbers increased in the STZ, where Oxytoxum laticeps became dominant and several further large-size species of Prorocentrum, Ceratium and Gymnodinium appeared in addition to those at the STF. The distribution of different biogeochemical parameters suggests that the Crozet Basin frontal region is a non-exporting system at the end of summer. During this postbloom period, biological activity is low and phytoplankton growth severely limited. This is evidenced by the weak dependence of the partial pressure of carbon dioxide $\left(\mathrm{pCO}_{2}\right)$ on biological activity and the importance of the air-sea exchange in maintaining $\mathrm{pCO}_{2}$ close to saturation.
\end{abstract}

KEY WORDS: Frontal zones $\cdot$ Nutrients $\cdot$ Biogenic silica $\cdot$ Chlorophyll $a \cdot \mathrm{pCO}_{2} \cdot$ Phytoplankton $\cdot$ Bacteria

Resale or republication not permitted without written consent of the publisher

\section{INTRODUCTION}

The Southern Ocean is characterized by the occurrence of several permanent circumpolar frontal sys- tems that form the eastward flowing Antarctic Circumpolar Current (ACC). The Subtropical Front (STF) represents the northern border of the ACC. It separates the warm and saline subtropical waters from the cool 
and less saline subantarctic waters. Southwards, the Subantarctic Front (SAF) and the Polar Front (PF) mark the transition between subantarctic and Antarctic waters. The fronts mark the boundaries between different zones of the ACC: the Subantarctic Zone (SAZ) between the STF and the SAF, and the Polar Frontal Zone (PFZ) between the SAF and PF (Nowlin \& Klinck 1986). Although this structure is circumpolar, the position of the different fronts is determined by the spatial pattern of the wind field, bottom topography and seasonal variability (Deacon 1982, Gamberoni et al. 1982, Piola et al. 1987). The Crozet Basin shows a complex circulation pattern in contrast to other frontal regions of the ACC. Due to the northwards bend of the ACC across the Crozet Plateau, the SAF and STF are tightly coalesced and form a concentrated jet merging with the Agulhas Return Current (ARC) (Park et al. 1991, 1993).

The Southern Ocean is considered, together with the subarctic and equatorial Pacific Ocean, to be a highnutrient, low-chlorophyll (HNLC) region. However, in situ studies and satellite observations indicate higher productivity and chlorophyll biomass in a variety of disparate regions. Phytoplankton blooms have been observed in the marginal ice zone (Smith \& Nelson 1990, Sullivan et al. 1993), around islands (Perissinotto et al. 1992, 2000, Pakhomov \& Froneman 1999, Blain et al. 2001) and along frontal zones (Laubscher et al. 1993, Bathmann et al. 1997). Fronts are regions of strong horizontal temperature and/or salinity gradients that may occur in lakes, rivers and oceans (Franks 1992). Phytoplankton blooms are closely related to fronts in the oceans. Like other oceanic frontal regions, the Crozet Basin exhibits high levels of chlorophyll concentration during summer (Weeks \& Shillington 1996, Metzl et al. 1991). The biomass enhancement is generally associated with low $\mathrm{pCO}_{2}$ values (Metzl et al. 1999). This strong sink of atmospheric $\mathrm{CO}_{2}$, considered one of the most important in the Southern Ocean, may result from physical mechanisms and biological processes (Metzl et al. 1998).

Previous studies have mainly focused on the PF (ElSayed \& Weber 1982, Fiala et al. 1998a,b, Hense et al. 2000). In contrast, little is known about the STF in spite of its importance as an efficient hydrodynamical barrier for various organisms (Clementson et al. 1998, Bradford-Grieve et al. 1999, Froneman et al. 1999). The STF is characterized by a sharp horizontal gradient in temperature and salinity which separates water masses of different physico-chemical properties. It exhibits dramatic changes in the diversity and distribution of phytoplankton, zooplankton (Furuya et al. 1986, Froneman et al. 1995, Barange et al. 1998), fishes (Roberts 1980) and birds (Pakhomov \& McQuaid 1996). The STF also exhibits biomass and production enhancements (Weeks \& Shillington 1996, Gall \&
Hawes 1999, Read et al. 2000). Because of its large circumpolar extension, it is a major contributor to the global ocean production (Dower \& Lucas 1993). Several factors could explain the biomass enhancement in the vicinity of fronts, including increased in situ production resulting from strong water stratification due to the mixing of the warm subtropical water with the cold subantarctic water (Laubscher et al. 1993, Bradford-Grieve et al. 1997) and a passive transport of cells (Van Ballegooyen et al. 1994). Biomass enhancement can also result from the formation of eddies that move across the STF transporting heat, salt and nutrients into the surrounding environment (Froneman et al. 1999, Read et al. 2000). The Crozet Basin frontal zone corresponds to one of the strongest eddy activity areas of the Southern Ocean. SeaWiFS images have revealed the omnipresence of isolated eddies each side of the Agulhas Front (AF) (Park et al. 2002).

The present study focused on the fine spatial distribution of a large set of parameters in the surface waters of the Crozet Basin in an area crossed by the ACC and encompassing the transition from cold subantarctic to warm subtropical waters. Our purpose was to gain information about the influence of hydrological fronts on the distribution of the biogeochemical parameters and the phytoplankton community during late austral summer.

\section{MATERIALS AND METHODS}

Study area. A mesoscale study was conducted over 15 d (22 January to 5 February 1999) in the Crozet Basin frontal zone during the 'Antares 4' cruise on board the RV 'Marion Dufresne 2'. The survey area lay within the southernmost and easternmost convergence zone of the ACC and the ARC. The investigated region was delimited by a fine grid bounded by a parallelogram of $1.5^{\circ}$ latitude $\times 2^{\circ}$ longitude $(\sim 200 \times 200 \mathrm{~km})$ between $43^{\circ} 50^{\prime}$ and $45^{\circ} 20^{\prime} \mathrm{S}$ and between $61^{\circ} 00^{\prime}$ and $64^{\circ} 30^{\prime} \mathrm{E}$. The grid was composed of $9 \mathrm{SW}-\mathrm{NE}$ parallel transects separated by distances of $\sim 20 \mathrm{~km}$ (see Fig. 1).

Sampling. Surface seawater was sampled from the ship's continuous flow-through system ( 7 m depth bow inlet) during the deployment of an undulating TowYo vehicle (Prieur \& Sournia 1994). The vehicle was towed at $\sim 4$ knots and surface samples were collected along the grid from the flow-through system at regular intervals: $7.4 \mathrm{~km}$ for partial pressure of carbon dioxide $\left(\mathrm{pCO}_{2}\right)$, nutrients concentration and flow cytometry measurements, $14.8 \mathrm{~km}$ for chlorophyll a (chl a) concentration and $29.6 \mathrm{~km}$ for optical microscopy cell counting.

Methods. Salinity and temperature were recorded at $7.4 \mathrm{~km}$ intervals using a Seabird thermosalinograph 
and a Falmouth Scientific Instruments temperature sensor.

Nitrate and silicic acid were determined on board via a standard automated method (Tréguer \& Le Corre 1975)

For particulate silica analysis, 11 samples were filtered onto $0.6 \mu \mathrm{m}$ Nuclepore polycarbonate filters. Filters were then oven-dried $\left(60^{\circ} \mathrm{C}\right)$ on board, stored in plastic petri dishes, and returned to the laboratory for further analysis. Biogenic silica (BSi) was measured by the hot $\mathrm{NaOH}$ digestion method of Paasche (1973) as modified by Nelson et al. (1989) (blanks: $0.006 \pm$ $0.005 \mu \mathrm{m}$; precision: $< \pm 10 \%$ in the range 0 to $20 \mu \mathrm{m}$ ). After $\mathrm{NaOH}$ extraction, filters were assayed for lithogenic silica (LSi) by fluorhydric acid addition according to the method described by Ragueneau \& Tréguer (1994) (blanks: $0.011 \pm 0.006 \mu \mathrm{m}$; precision: $< \pm 10 \%$ in the range 0 to $20 \mu \mathrm{m})$.

$\mathrm{pCO}_{2}$ was measured using an equilibrator coupled to a non-dispersive infrared gas analyzer (Li-Cor, LI-6262). The equilibrator consists of a Plexiglas cylinder (height: $80 \mathrm{~cm}$; diameter: $10 \mathrm{~cm}$ ) filled with marbles to increase the exchange surface area (Frankignoulle et al. 2001). Seawater runs (3 $1 \mathrm{~min}^{-1}$ ) from the top to the bottom of the equilibrator and air is pumped upward $\left(31 \mathrm{~min}^{-1}\right)$. The temperature at the outlet of the equilibrator was monitored using a platinum resistance thermometer (Metrohm). $\mathrm{pCO}_{2}$ values were corrected for the temperature difference between seawater in situ and in the equilibrator using the algorithm proposed by Copin-Montégut (1988, 1989). The Li-Cor analyzer was calibrated once a day with 2 gas standards of 0 and 345.4 ppm, respectively.

Chl a concentrations were measured on board after filtration of $1 \mathrm{l}$ seawater onto a $47 \mathrm{~mm}$ Whatman GF/F glass-fibre filter at a vacuum differential of $<20 \mathrm{~cm} \mathrm{Hg}$. Filters were ground manually in $100 \%$ acetone (water retention in the filter brought the final concentration to $90 \%$ ) and extraction was carried out in the dark for $24 \mathrm{~h}$ at $5^{\circ} \mathrm{C}$. The fluorescence of the acetone extract was measured on a Perkin Elmer MPF 66 spectrofluorometer (Neveux \& Panouse 1987).

For flow cytometry analysis, prefiltered samples (100 $\mathrm{mm}$ mesh-size net) were fixed with $2 \%$ paraformaldehyde (Trousselier et al. 1995) and frozen in liquid nitrogen until later analysis in the laboratory. Just before analysis, samples were rapidly thawed in a $30^{\circ} \mathrm{C}$ water bath and fluorescent beads of 1 or $10 \mu \mathrm{m}$ diameter were added to normalize the flow cytometer setting and to provide a reference for concentration calculations. Samples were analysed using a Cytoron Absolute (Ortho Diagnostic Systems) flow cytometer, with a $488 \mathrm{~nm}$ air-cooled argon laser. Each cell was characterized by 5 optical parameters: forward-scatter (linked to cell size) and right-angle scatter (linked to cell struc- ture) and red (>620 nm), orange (565 to $592 \mathrm{~nm}$ ) and green (515 to $530 \mathrm{~nm}$ ) fluorescences. Counting varied by $<3.7 \%$ SD $(n=23)$ over a range of concentrations covering 1 order of magnitude. Data were collected and stored in list-mode with the Immunocount software (Ortho Diagnostic Systems). Analyses were run with the Winlist software (Verity Software House). The flow cytometric analysis was restricted to $<10 \mu \mathrm{m}$ phytoplanktonic cells. Heterotrophic bacteria were counted after staining. For this purpose, $1 \mathrm{ml}$ of seawater was supplemented with $10 \mu \mathrm{l}$ SybrGreen II (from the molecular probes solution diluted $10 \times$ ) and incubated for $10 \mathrm{~min}$ in the dark before analysis.

Aliquots of $100 \mathrm{ml}$ seawater were sampled for taxonomic analysis and enumeration of phytoplankton communities. They were preserved with formalin (final concentration $0.4 \%$ ) and stored in the dark at room temperature until laboratory analysis. Cells were counted using an Olympus inverted microscope according to procedures described by Utermöhl (1958). Due to sample preservation and optical resolution, the inverted microscope counting technique underestimates the pico-size species.

Statistical analysis. To determine the importance of hydrological features in structuring the planktonic community, we used 2 connected statistical methods. In a first step, ordination by principal components analysis (PCA; Statgraphics Plus software) was used to define hydrographic regions based on similarities in temperature, salinity, $\mathrm{pCO}_{2}$ and nutrients (nitrates and silicates). The values of the variables were standardised by subtracting their means and dividing by their standard deviations. In a second step, hierarchical cluster analysis in the space of the first principal components was used to gather hydrologically similar stations. The dissimilarity between clusters was calculated using average values. The average distance was calculated from the distance between each point in a cluster and all other points in another cluster. Euclidean distances between values were measured.

\section{RESULTS}

\section{Frontal structure within area investigated}

The different front locations (Fig. 1) were determined using temperature and salinity measurements from 200 m depth (Park et al. 2002). These fronts can be considered representative of the surface hydrological structure although some slight deviations occur (i.e. the more southwards direction of the SAF/STF in the eastern part of the survey area). A detailed description of the large-scale frontal circulation within the entire Crozet Basin during this cruise has been given by Park 
et al. (2002), but can be summarized thus: at the entrance to the Crozet Basin at $50^{\circ} \mathrm{E}$, the $\mathrm{ACC}$ and ARC merged to form a frontal system composed of the SAF, STF and AF. Moving eastwards the SAF and STF shifted southwards. They reconverged most strongly at $63^{\circ} 30^{\prime} \mathrm{E}$, due to a sharp meandering northwards (Fig. 1). A number of mesoscale meanders and eddies were superimposed on the main basin circulation. Meanders show an irregular configuration, continually evolving with time. Cyclonic and anticyclonic eddies with a diameter of 150 to $200 \mathrm{~km}$ were present at regular intervals of 300 to $500 \mathrm{~km}$. The survey grid was bordered by the edge of 2 cyclonic eddies in its southwestern and eastern corners and by the southern edge of an anticyclonic eddy to the north (Park et al. 2002).

The northern part of the survey grid intercepted the $A F$, whereas its south-east domain encompassed the SAF and STF (Fig. 1). The fronts defined the boundaries between 3 relatively homogeneous zones: (1) the PFZ located southwards, between the SAF and PF; (2) the STZ located north of the STF and AF; (3) the SAZ which was reduced to a narrow band in the investigated region due to the coalescence of the SAF and STF.

\section{Surface temperature and salinity distributions}

The SE-NW transition between the PFZ and STZ was marked by a sharp increase in temperature and salinity. Temperature $(\mathrm{T})$ of the surface water increased from 10 to $16.5^{\circ} \mathrm{C}$ over a distance of $170 \mathrm{~km}$ and salinity (S) increased from 33.8 to 35.2 over the same distance (Fig. 2a,b). The PFZ surface water, south of the SAF-STF, was colder $\left(11.2^{\circ} \mathrm{C}\right)$ and less saline $(<33.8)$ than the northern subtropical surface water $\left(12.5^{\circ} \mathrm{C}\right.$ $<\mathrm{T}<15.5^{\circ} \mathrm{C}$ and $34.3<\mathrm{S}<35.0$ ) (Table 1 ).

\section{Surface nutrient distribution}

Nitrate concentrations mirrored the frontal structure. They followed a negative gradient from south to north, decreasing sharply from $16 \mu \mathrm{M}$ in the southeast to $<1 \mu \mathrm{M}$ in the northwest (Fig. 2c). Nitrate values were $>16 \mu \mathrm{M}$ in PFZ waters and between 2 and $9 \mu \mathrm{M}$ in STZ waters. The frontal region (SAF/STF) exhibited concentrations between 7 and $15 \mu \mathrm{M}$. North of the AF, surface waters showed nitrate depletion (Table 1).

In contrast, silicic acid concentrations did not show a well-defined gradient (Fig. 2d). The concentrations were low over the study area, with values from 0.1 to $1.4 \mu \mathrm{M}$. South of the AF the surface concentrations were between 0.2 and $0.9 \mu \mathrm{M}$; north of the $\mathrm{AF}$, the values increased slightly, with a maximum of $>1 \mu \mathrm{M}$.

\section{Biogenic and lithogenic silica distribution}

Biogenic silica (BSi) concentrations were low throughout the study area (Fig. 3a). BSi distribution more or less matched the position of the frontal structure. Very low values $(0.02$ to $0.15 \mu \mathrm{mol}$ $\mathrm{l}^{-1}$ ) were observed in the northern area that corresponded to the occurrence of warmer and more saline subtropical waters. In the subantarctic waters, BSi concentrations increased northwards from 0.02 to $0.34 \mu_{\mathrm{mol} \mathrm{l}} \mathrm{l}^{-1}$ (Table 1 ). The maximum value was recorded at the eastern boundary of the study area in the coalescent SAF and STF.

Lithogenic silica (LSi) was less abundant than BSi in the whole study area. The distribution pattern was also closely related to the frontal structure (Fig. 3b). LSi values were at the detection limit in
Fig. 1. Location of survey grid (9 parallel SW-NE transects) along which surface-water samples were collected during Cruise 'Antares 4' (January to February 1999). Positions of the different fronts are shown (identified at $200 \mathrm{~m}$ depth: Park et al. 2002). SAF: Subantarctic Front; STF: Subtropical front AF: Agulhas Front 

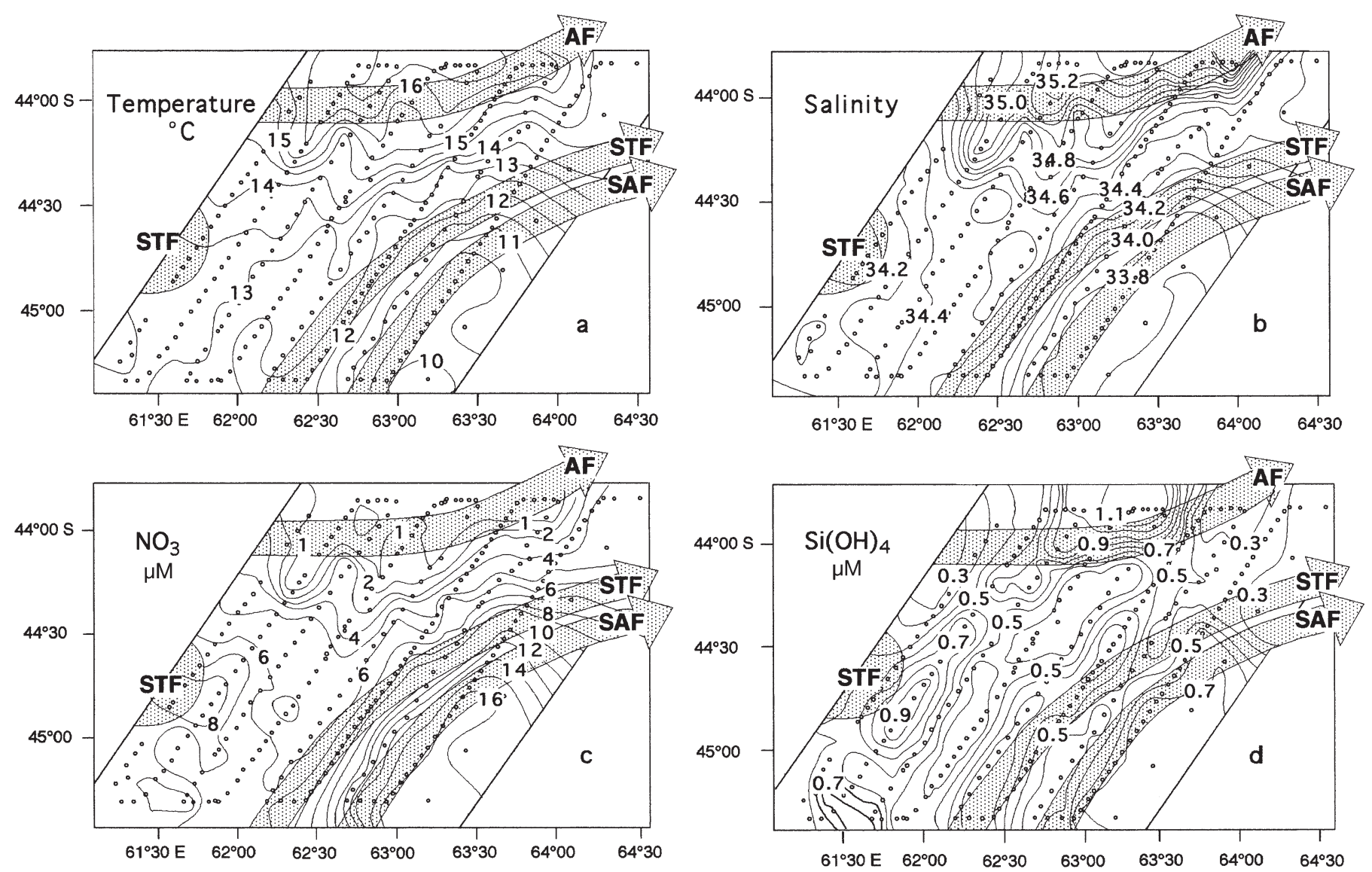

Fig. 2. Surface distribution of (a) temperature, (b) salinity, (c) nitrate concentration and (d) silicic acid concentration in the Crozet Basin during late summer. Here and in Figs. 3 to 5, sampling stations are indicated by dots, and abbreviations are as in Fig. 1; shaded arrows indicate direction of fronts

Table 1. Temperature, salinity, nitrate, silicic acid (Si), biogenic silica (BSi), lithogenic silica (LSi), chlorophyll a (chl a) and pCO ${ }_{2}$ in the 4 hydro-chemical clusters determined by statistical analysis. PFZ: Polar Frontal Zone; STZ: Subtropical Zone; AF: Agulhas Front

\begin{tabular}{|c|c|c|c|c|c|c|c|c|}
\hline Cluster & $\begin{array}{c}\text { Temperature } \\
\left({ }^{\circ} \mathrm{C}\right)\end{array}$ & Salinity & $\begin{array}{l}\text { Nitrate } \\
(\mu \mathrm{M})\end{array}$ & $\begin{array}{c}\mathrm{Si} \\
(\mu \mathrm{M})\end{array}$ & $\begin{array}{c}\mathrm{BSi} \\
\left(\mu \mathrm{mol} \mathrm{l}{ }^{-1}\right)\end{array}$ & $\begin{array}{c}\mathrm{LSi} \\
\left(\mu \mathrm{mol} \mathrm{l^{-1 }}\right)\end{array}$ & $\begin{array}{l}\text { Chl } a \\
\left(\mu \mathrm{g} \mathrm{l}^{-1}\right)\end{array}$ & $\begin{array}{c}\mathrm{pCO}_{2} \\
(\mu \mathrm{atm})\end{array}$ \\
\hline \multicolumn{9}{|l|}{ Cluster 1 (PFZ) } \\
\hline Mean $( \pm \mathrm{SD})$ & $11.22 \pm 0.59$ & $33.80 \pm 0.06$ & $14.42 \pm 1.90$ & $0.58 \pm 0.18$ & $0.06 \pm 0.07$ & $0.02 \pm 0.02$ & $0.17 \pm 0.08$ & $351.5 \pm 12.5$ \\
\hline Range & $9.87-12.6$ & $33.76-33.98$ & $10.4-17.1$ & $0.2-0.9$ & $0.02-0.30$ & $0.00-0.07$ & $0.08-0.37$ & $329.0-371.3$ \\
\hline Sample no. & 39 & 39 & 39 & 39 & 13 & 13 & 22 & 39 \\
\hline \multicolumn{9}{|l|}{ Cluster 2 (STZ) } \\
\hline Mean $( \pm \mathrm{SD})$ & $13.81 \pm 0.85$ & $34.38 \pm 0.14$ & $6.11 \pm 1.66$ & $0.55 \pm 0.19$ & $0.11 \pm 0.05$ & $0.02 \pm 0.01$ & $0.41 \pm 0.10$ & $318.7 \pm 7.2$ \\
\hline Range & $12.51-15.85$ & $34.09-34.70$ & $2.4-9.4$ & $0.2-1.0$ & $0.03-0.34$ & $0.00-0.06$ & $0.2-0.81$ & $305.3-344.7$ \\
\hline Sample no. & 170 & 170 & 170 & 170 & 44 & 44 & 90 & 170 \\
\hline \multicolumn{9}{|l|}{ Cluster 3 (AF) } \\
\hline Mean $( \pm \mathrm{SD})$ & $16.47 \pm 0.51$ & $35.05 \pm 0.16$ & $0.62 \pm 0.94$ & $0.43 \pm 0.19$ & $0.07 \pm 0.02$ & $0.01 \pm 0.01$ & $0.38 \pm 0.12$ & $304.3 \pm 3.8$ \\
\hline Range & $14.98-16.96$ & $34.72-35.28$ & $0.00-3.40$ & $0.1-0.8$ & $0.04-0.10$ & $0.00-0.02$ & $0.21-0.65$ & $298.9-313.5$ \\
\hline Sample no. & 34 & 34 & 34 & 34 & 10 & 10 & 17 & 34 \\
\hline \multicolumn{9}{|c|}{ Cluster 4 (North AF) } \\
\hline Mean $( \pm \mathrm{SD})$ & $17.03 \pm 0.39$ & \pm 0.12 & $0.33 \pm 0.45$ & $1.12 \pm 0.14$ & $0.05 \pm 0.01$ & $0.10 \pm 0.0$ & $0.27 \pm 0.05$ & $310.9 \pm 4.6$ \\
\hline Range & $16.06-17.37$ & $35.00-35.43$ & $0.0-1.7$ & $0.9-1.4$ & $0.05-0.06$ & $0.00-0.01$ & $0.19-0.34$ & $303.3-315.7$ \\
\hline Sample no. & 18 & 18 & 18 & 18 & 4 & 4 & 8 & 18 \\
\hline
\end{tabular}


western subtropical waters. Higher values were observed in eastern subantarctic waters, but they did not exceed $0.07 \mu_{\mathrm{mol} \mathrm{l}} \mathrm{l}^{-1}$ (Table 1).

\section{Chl a distribution}

Like other parameters, chl a distribution was strongly influenced by the frontal structure. The southern waters of the PFZ were poor in chl $a$, with concentrations of $<0.4 \mu \mathrm{g} \mathrm{l}^{-1}$ (Fig. 3c). Northwards, the concentrations increased to $0.30-0.50 \mu \mathrm{g} \mathrm{chl} \mathrm{a} \mathrm{l^{-1 }}$ in the central part of STZ (Table 1). At the northeastern border of the STF, chl a values reached a maximum of $0.81 \mu \mathrm{g} \mathrm{l}^{-1}$.

\section{$\mathrm{pCO}_{2}$ distribution}

Over the study area, surface-water $\mathrm{pCO}_{2}$ ranged from a slight supersaturation (>360 $\mu \mathrm{atm}$, the equilibrium value) to a net undersaturation $(<300 \mu \mathrm{atm})$.
The $\mathrm{pCO}_{2}$ distribution was closely related to the frontal structure (Fig. 3d). The merged SAF and STF marked the boundary between the saturated PFZ waters (360 to $370 \mu \mathrm{atm})$ and the northern undersaturated STZ waters (310 to $330 \mu \mathrm{atm})$. The lowest values ( 300 $\mu \mathrm{atm})$ were observed in the warm and saline subtropical waters (Table 1). In the southeastern part of the grid, the $\mathrm{pCO}_{2}$ increase was associated with the STF meander covered by the grid.

\section{Phytoplankton abundance determined by flow cytometry (FCM)}

Three phytoplankton groups were identified by FCM analysis with regard to size and fluorescence characteristics (Li 1994): picoeukaryotes $(<3 \mu \mathrm{m})$, nanoeukaryotes (3 to $10 \mu \mathrm{m})$ and cyanobacteria $(<1.5 \mu \mathrm{m})$.

Picophytoplankton cells were present throughout the area investigated (Fig. 4a). The highest abundance was observed in the STZ (from 4 to $10 \times 10^{6}$ cells $\mathrm{l}^{-1}$ ) with a

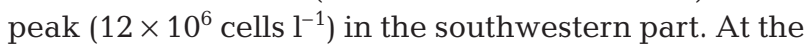
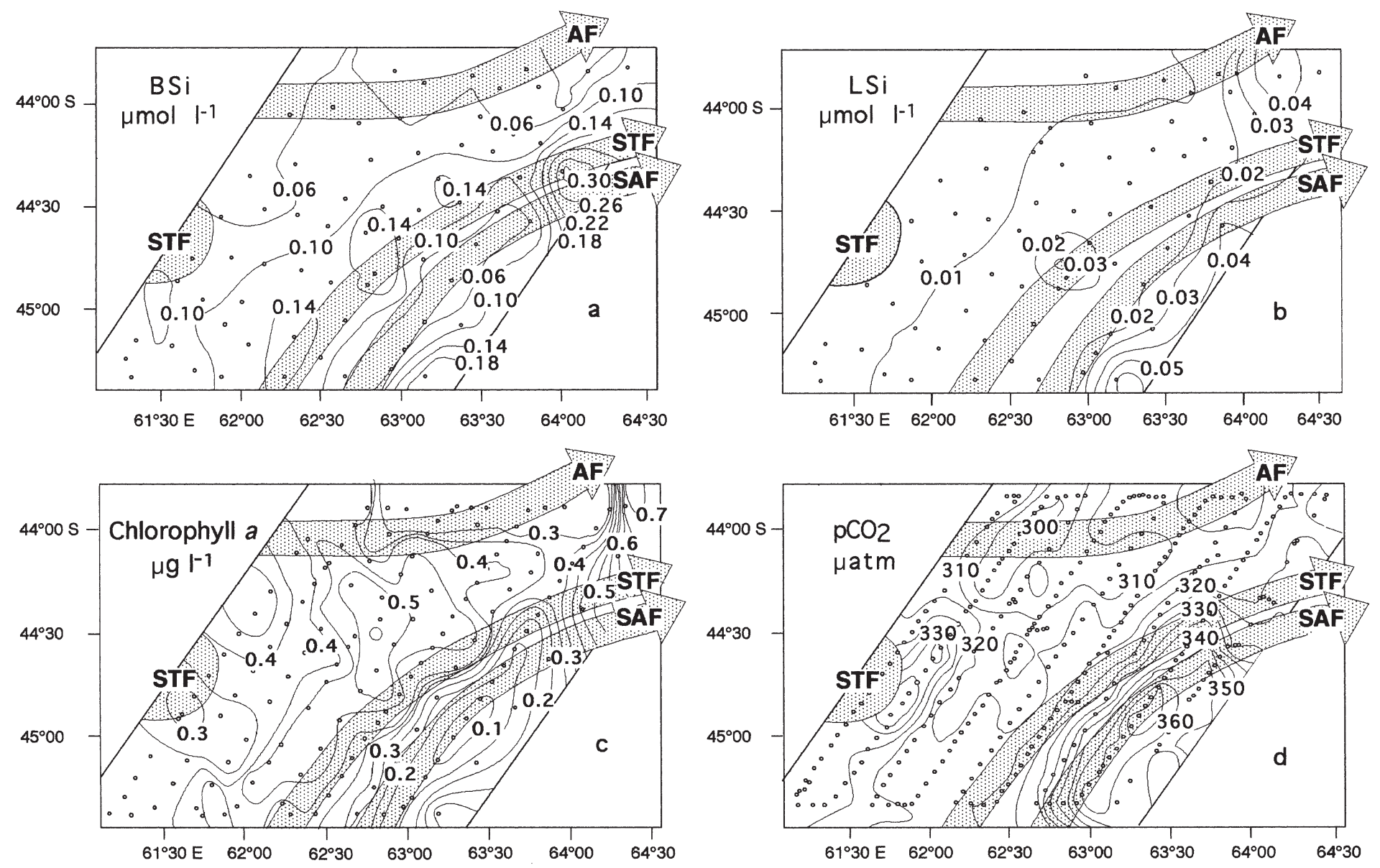

Fig. 3. Surface distribution of (a) biogenic silica concentration, (b) lithogenic silica concentration, (c) chl a concentration and (d) $\mathrm{pCO}_{2}$ 

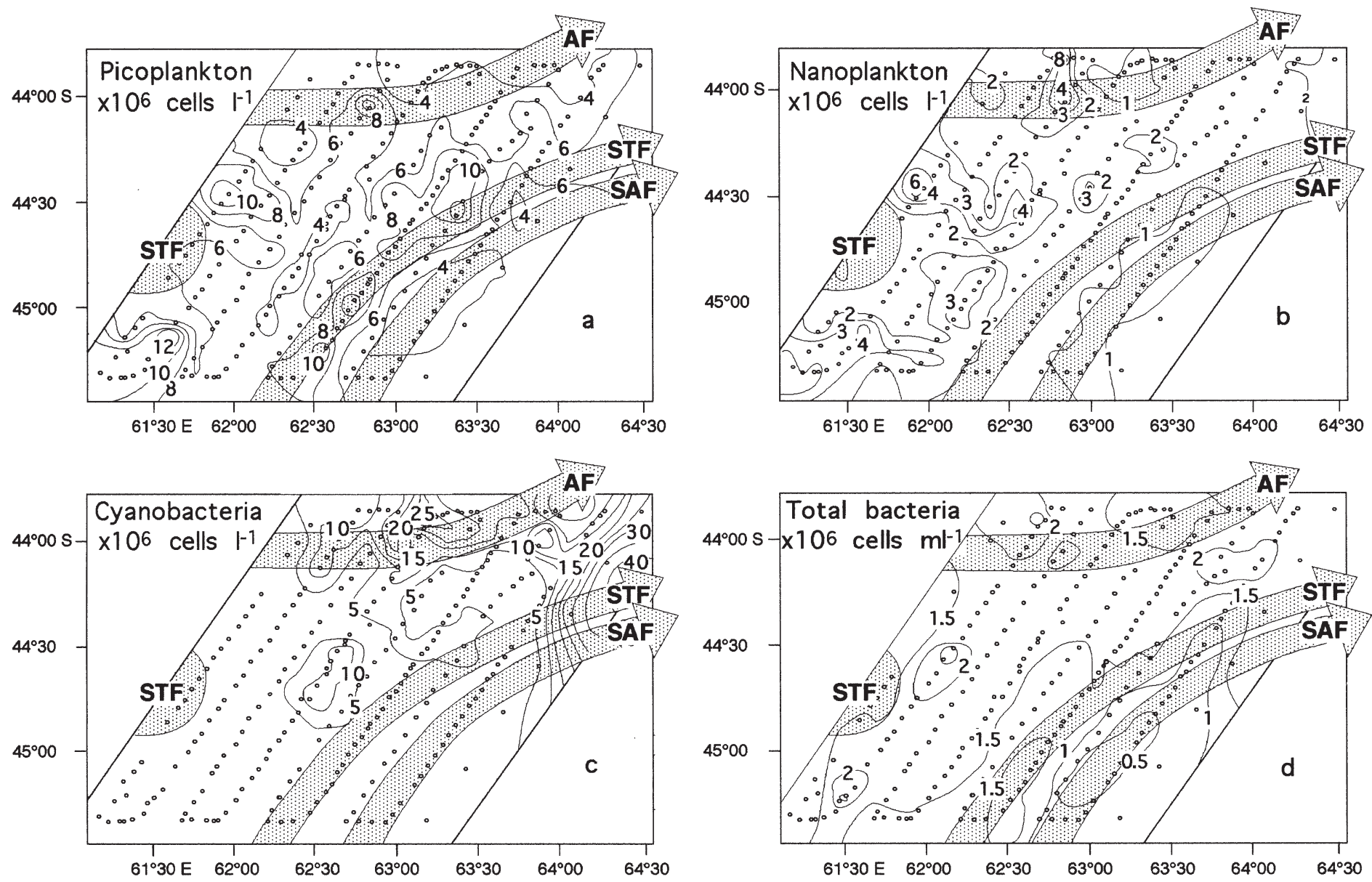

Fig. 4. Surface distribution of (a) picoplankton, (b) nanoplankton, (c) cyanobacteria and (d) total bacteria as measured by flow cytometry (FCM)

STF, picoplankton cells were also abundant $\left(6\right.$ to $10 \times 10^{6}$ cells $\mathrm{l}^{-1}$ ) whereas the SAF and the PFZ had the lowest concentrations (Table 2). Surface distribution of nanophytoplankton (Fig. 4b) was similar to that of picoplankton except at the STF, where they did not exhibit any special feature. Nanoplankton abundance (up to $8 \times$

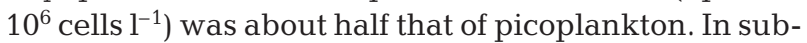
antarctic waters, their abundance was low $\left(\sim 10^{6}\right.$ cells $\left.\mathrm{l}^{-1}\right)$ (Table 2). Cyanobacteria were only present in subtropical waters $\left(>12.5^{\circ} \mathrm{C}\right.$ ) (Fig. $4 \mathrm{C}$ ) and their peaks of abundance ( 2 to $5 \times 10^{7}$ cells $\mathrm{l}^{-1}$ ) occurred in the warmer waters of the STZ and in the AF (Table 2). In the northern subtropical waters, cyanobacteria were dominant and contributed $68 \%$ to total phytoplankton numbers, whereas picoeukaryotes only contributed $23 \%$. On the other hand, in the southern STZ, picoeukaryotes were dominant (61\%). In the cold and low-salinity waters of the PFZ, picoplanktonic cells were dominant; they contributed $76 \%$ to total phytoplankton abundance compared to $15 \%$ for nanoplankton.

\section{Heterotrophic bacteria}

Heterotrophic bacteria concentrations ranged from $0.5 \times 10^{6}$ to $>2 \times 10^{6}$ cells ml $^{-1}$ (Fig. $4 \mathrm{~d}$ ). They were present throughout the entire area investigated. However, their abundance remained at $<1.2 \times 10^{6}$ cells $\mathrm{ml}^{-1}$ south of the STF. Peak abundance (up to $2.5 \times 10^{6}$ cells $\mathrm{ml}^{-1}$ ) was observed in the STZ (Table 2).

\section{Microscope analysis of the phytoplankton community}

Phytoplankton populations were composed, in order of decreasing abundance, of picoplankton $(\sim 2 \mu \mathrm{m})$ and naked nanoflagellates (3 to $20 \mu \mathrm{m})$, dinoflagellates (8 to $300 \mu \mathrm{m})$, coccolithophorids (5 to $30 \mu \mathrm{m}$ ) and diatoms (5 to $600 \mu \mathrm{m}$ ). Variations in cell numbers of the major phytoplankton groups in surface waters were 
Table 2. Picoplankton, nanoplankton, pico- and nanoflagellates, dinoflagellates, cyanobacteria, coccolithophorids, diatoms and total bacteria in the 4 hydrochemical clusters determined by statistical analysis. Region abbreviations as in Table 1

\begin{tabular}{|c|c|c|c|c|c|c|c|c|}
\hline Cluster & $\begin{array}{l}\text { Picoplankton } \\
\left(\times 10^{6}{\left.\text { cells } 1^{-1}\right)}^{-1}\right.\end{array}$ & $\begin{array}{c}\text { Nanoplankton } \\
\left(\times 10^{6} \text { cells l}^{-1}\right)\end{array}$ & $\begin{array}{c}\text { Pico- + nano- } \\
\text { flagellates } \\
\left(\times 10^{6} \text { cells } ~^{-1}\right)\end{array}$ & $\begin{array}{c}\text { Dinoflagellates } \\
\left(\times 10^{3} \text { cells l}^{-1}\right)\end{array}$ & $\begin{array}{c}\text { Cyano- } \\
\text { bacteria } \\
\left(\times 10^{6} \text { cells l }^{-1}\right)\end{array}$ & $\begin{array}{l}\text { Coccolitho- } \\
\text { phorids } \\
\left(\times 10^{3} \text { cells } 1^{-1}\right)\end{array}$ & $\begin{array}{c}\text { Diatoms } \\
\left(\times 10^{3} \text { cells l }^{-1}\right)\end{array}$ & $\begin{array}{c}\text { Total } \\
\text { bacteria } \\
\left(\times 10^{6} \text { cells } 1^{-1}\right)\end{array}$ \\
\hline \multicolumn{9}{|l|}{ Cluster 1 (PFZ) } \\
\hline Mean $( \pm \mathrm{SD})$ & $3.7 \pm 1.3$ & $0.8 \pm 0.3$ & $0.25 \pm 0.12$ & $41.9 \pm 29.8$ & $0.6 \pm 1.3$ & $136.1 \pm 62.6$ & $19.9 \pm 9.8$ & $0.6 \pm 0.3$ \\
\hline Range & $1.3-6.5$ & $0.2-1.5$ & $0.09-0.50$ & $10.5-110.0$ & $0.0-6.6$ & $13.1-265.3$ & $6.6-36.8$ & $0.3-1.9$ \\
\hline Sample no. & 37 & 37 & 14 & 14 & 38 & 14 & 14 & 38 \\
\hline \multicolumn{9}{|l|}{ Cluster 2 (STZ) } \\
\hline Mean $( \pm \mathrm{SD})$ & $4.9 \pm 1.8$ & $2.1 \pm 1.2$ & $0.8 \pm 0.7$ & $232.0 \pm 119.4$ & $4.8 \pm 7.9$ & $164.4 \pm 73.0$ & $69.3 \pm 71.2$ & $1.6 \pm 0.4$ \\
\hline Range & $0.9-12.0$ & $0.6-6.3$ & $0.04-5.01$ & $50.2-519.3$ & $0.0-52.1$ & $59.6-337.3$ & $2.1-399.5$ & $0.7-0.3$ \\
\hline Sample no. & 162 & 162 & 40 & 40 & 161 & 40 & 40 & 137 \\
\hline \multicolumn{9}{|l|}{ Cluster 3 (AF) } \\
\hline Mean $( \pm \mathrm{SD})$ & $3.1 \pm 1.4$ & $1.4 \pm 0.3$ & $1.0 \pm 0.5$ & $144.3 \pm 81.2$ & $11.7 \pm 9.6$ & $171.6 \pm 77.7$ & $30.5 \pm 16.8$ & $1.7 \pm 0.4$ \\
\hline range & $1.4-7.5$ & $0.7-2.2$ & $0.27-1.93$ & $37.9-307.7$ & $0.4-40.3$ & $97.3-307.7$ & $15.5-68.4$ & $0.7-2.7$ \\
\hline Sample no. & 32 & 32 & 10 & 10 & 34 & 10 & 10 & 25 \\
\hline \multicolumn{9}{|c|}{ Cluster 4 (North AF) } \\
\hline Mean $( \pm \mathrm{SD})$ & $3.1 \pm 1.4$ & $1.7 \pm 2.1$ & $1.70 \pm 1.76$ & $58.5 \pm 1.6$ & $23.5 \pm 11.9$ & $153.5 \pm 77.8$ & $22.9 \pm 2.6$ & $1.4 \pm 0.2$ \\
\hline Range & $1.1-6.6$ & $0.6-8.8$ & $0.46-3.70$ & $57.3-59.6$ & $0-52$ & $98.5-208.6$ & $6.9-38.9$ & $1.1-1.8$ \\
\hline Sample no. & 16 & 16 & 2 & 2 & 18 & 2 & 2 & 15 \\
\hline
\end{tabular}
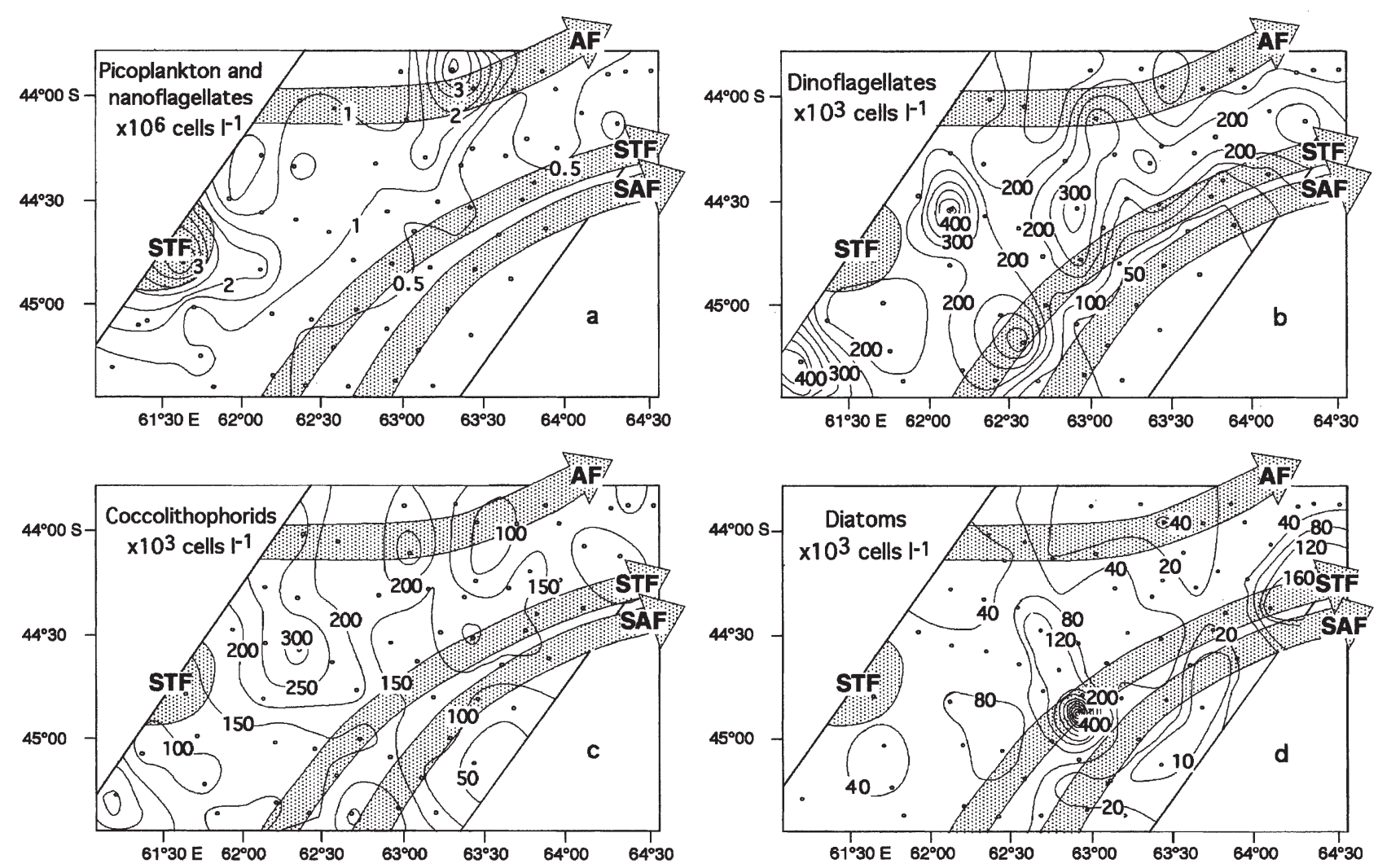

Fig. 5. Surface distribution of (a) picoplankton plus nanoflagellates $(<20 \mu \mathrm{m})$, (b) dinoflagellates, (c) coccolithophorids and (d) diatoms measured by microscope counting 
generally associated with changes in the frontal structure. A SE-NW positive gradient was observed in cell abundance. The combined groups of picoplankton plus naked nanoflagellates were remarkably similar south and north of the STF edge (cell numbers averaged $<2 \times 10^{5} \mathrm{l}^{-1}$ : Fig. 5a). Maxima of 2.0 to $5.0 \times$

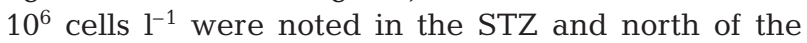
AF $\left(3.7 \times 10^{6} 1^{-1}\right)$ (Table 2). Nanoflagellates comprised prymnesiophytes, prasinophytes, cryptophytes and deflagellated, oval-shaped monads.

In the STZ, dinoflagellates varied between $2.0 \times$ $10^{5} \mathrm{l}^{-1}$ and ca. $4.0 \times 10^{5} \mathrm{l}^{-1}$ (Table 2). Maxima were recorded near the western STF meander and the northern part of the STF, with concentrations of 5.2 and $4.3 \times 10^{5}$ cells l$^{-1}$, respectively (Fig. $5 \mathrm{~b}$ ). South of the SAF, dinoflagellate numbers were lower than $5 \times 10^{4} \mathrm{l}^{-1}$ and consisted mainly of small gymnodinioid cells $(<18 \mu \mathrm{m})$ and Prorocentrum spp. A great change occurred within the STF, where both cell abundance and species numbers increased. Oxytoxum laticeps, present in very small quantities south of the STF, became dominant $\left(3 \times 10^{4} \mathrm{l}^{-1}\right)$, and was followed by O. variabile, O. parvum, several species of Gonyaulax, larger (>20 $\mu \mathrm{m})$ Gyrodinium spp., Gymnodinium spp., Prorocentrum spp., and Ceratium fusus. In the STZ, further new species appeared in addition to those at the STF: various Prorocentrum spp. ( $P$. rostratum, $P$. magnum, $P$. dentatum, $P$. triestinum), Ceratium lineatum, C. pentagonum, and large (40 to $70 \mu \mathrm{m}$ ) Gymnodinium/Gyrodinium spp. Oxytoxum laticeps and small gymnodinioid cells also remained dominant in this area. Quite a similar dinoflagellate species composition was observed at the AF.

Southwards in the PFZ, the numbers of coccolithophorids (max. 2.7 cells $\times 10^{5} \mathrm{l}^{-1}$ ) were 4 - to 5 -fold greater than those of dinoflagellates. Northwards they

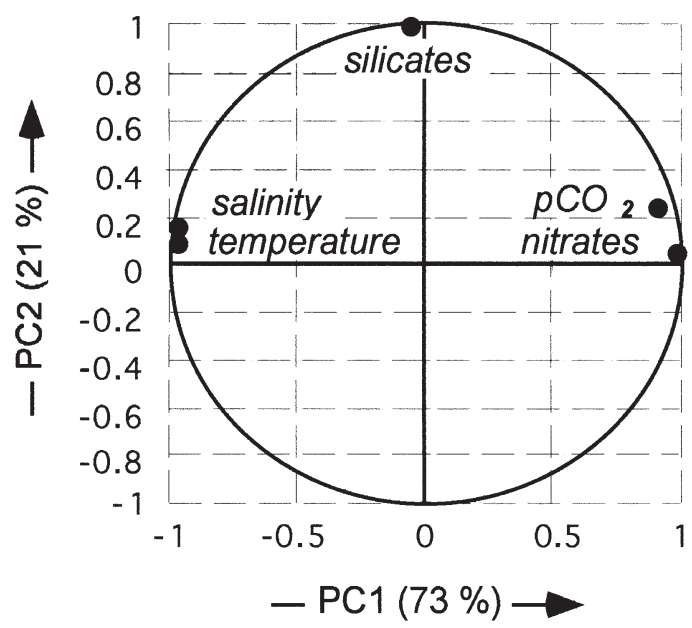

Fig. 6. Principal components analysis: plots of component weights were generally outnumbered by dinoflagellates at the STF and in the STZ (Fig. 5c). Maxima $\left(3.4 \times 10^{5}\right.$ cells l$\left.^{-1}\right)$ were observed in the central part of the STZ (Table 2). Emiliania huxleyi was the dominant species throughout the entire area of the study. Other frequently found species, with numbers increasing in the STZ, included Gephyrocapsa sp., Dactylethra sp., Halopappus sp., whereas species such as Syracosphaera sp. and Calyptrosphaera sp. were common north of the STF.

Diatoms were the least abundant group in the area investigated (Fig. 5d). Average cell numbers ranged between $2 \times 10^{4} \mathrm{l}^{-1}$ in the PFZ to $7 \times 10^{4} \mathrm{l}^{-1}$ in the STZ (Table 2). The highest cell numbers (8 to $12 \times 10^{4} \mathrm{l}^{-1}$ ) were found in the central STZ, with a maximum of $1.2 \times 10^{5} \mathrm{l}^{-1}$ north of the STF edge. Another peak was encountered within the STF $\left(4 \times 10^{5} \mathrm{l}^{-1}\right)$. Within the $\mathrm{AF}$, cell numbers were lower (average $3.0 \times 10^{4} \mathrm{l}^{-1}$ ). Diatoms were represented mainly by a few species of Pseudonitzschia (e.g. P. turgidula, P. heimii, P. delicatissima) which reached a peak in subtropical waters. Various species of Nitzschia ( $N$. longissima, N. closterium, $N$. bicapitata) and Thalassiothrix spp. were also common in the STZ.

During the survey, Phaeocystis antarctica was only observed in a few samples from the northern SAF-STF edge, with highest counts of $6 \times 10^{4} \mathrm{l}^{-1}$ north of the STF (data not shown).

\section{Statistical analysis}

PCA was used to determine the influence of physical and chemical parameters (temperature, salinity, nitrates, silicic acid and $\mathrm{pCO}_{2}$ ) on phytoplankton community distribution in the study area. Two principal components were extracted which account for $95.0 \%$ of the variability in the original data. The first principal component (PC1) accounts for $73.6 \%$ of the variance and gives positive weighting to nitrates and $\mathrm{pCO}_{2}$, and negative weighting to salinity and temperature (Fig. 6). The second principal component (PC2) accounts for $21.4 \%$ of the variance and gives general positive weights to all parameters, with the highest weight to silicates.

A hierarchical cluster analysis applied with the 2 first principal components as variables distinguished 4 clusters. Clusters 1, 2 and 3 are well separated along the PC1 axis, and PC2 allows the discrimination between Clusters 3 and 4. (Fig. 7). The correspondence between clusters and hydrological structures clearly appears in Fig. 8. Cluster 1 regroups stations located in the PFZ; Cluster 2 is occupied by stations located in the STZ; Cluster 3 gathers stations located in the $\mathrm{AF}$ region. Cluster 4, located north of the $\mathrm{AF}$, is characterized by the highest concentrations of silicates (1 to $1.4 \mu \mathrm{M})$. 


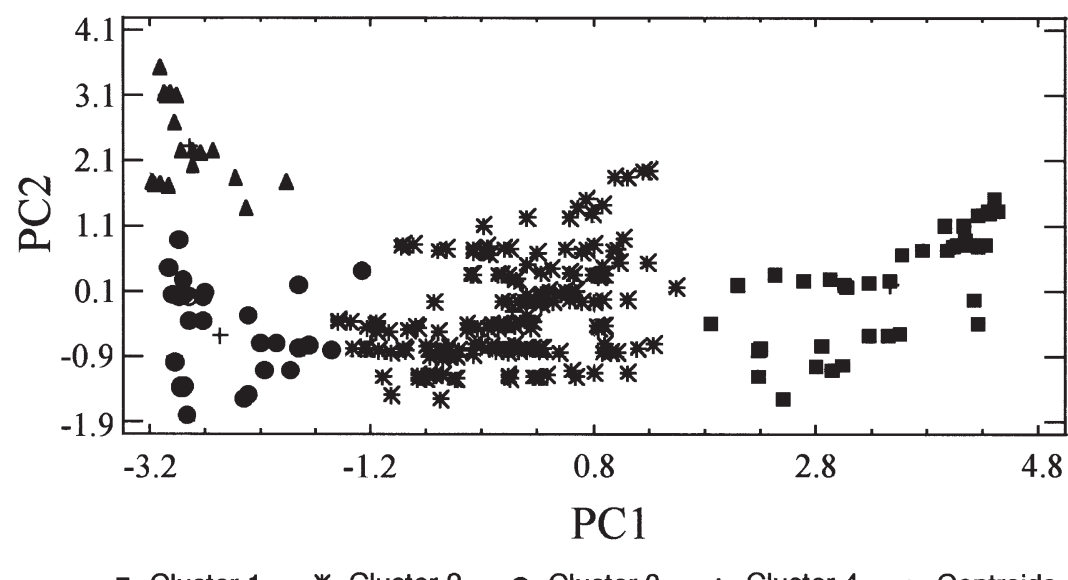

Fig. 7. Two-dimensional scatterplot of the clustered observations (261 sampled stations) versus the 2 variables: first principal component (PC1) and second principal component (PC2)

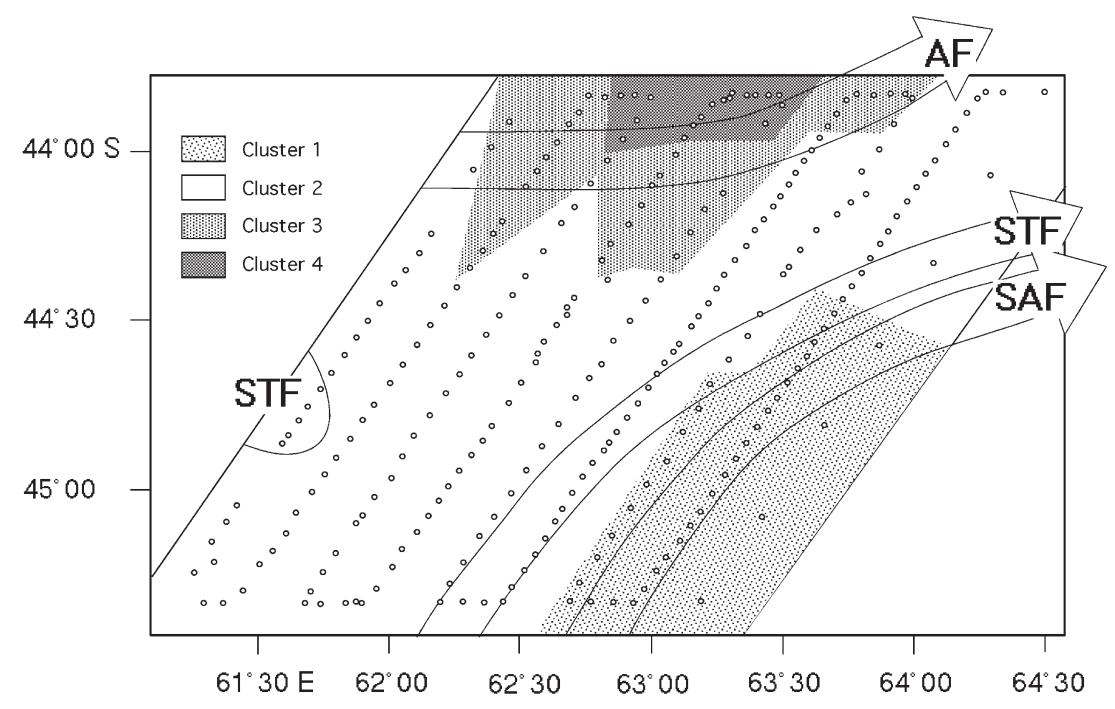

Fig. 8. Clustering of sample stations derived from statistical analysis

\section{DISCUSSION}

One major point of interest in the investigated area is that it covers the zone in which 3 oceanic fronts (SAF, STF and AF) converge. It therefore encompasses large gradients of temperature $\left(10.0\right.$ to $\left.16.5^{\circ} \mathrm{C}\right)$ and salinity (33.6 to 35.2$)$ over a short distance $(\sim 170 \mathrm{~km})$ in the northwards transition from subantarctic to subtropical waters. Statistical analysis confirms that physicochemical parameters were determinant in the distinction of 2 main regions, the southern PFZ and the northern STZ separated by a merged frontal system.

In the PFZ (Cluster 1) chl a concentrations were low $\left(<0.3 \mu \mathrm{g}^{-1}\right)$ despite the presence of large amounts of nitrate $(>15 \mu \mathrm{M})$. However, low concentrations of sili- cic acid were detected $(0.7 \mu \mathrm{M})$. This situation is typical of the PFZ waters during late summer (Dafner \& Mordasova 1994, Fiala et al. 1998a, Kopczynska et al. 2001). Particulate biogenic silica concentration in the surface waters was low and never exceeded $0.2 \mu \mathrm{mol} \mathrm{l}^{-1}$, reflecting a weak diatom contribution to phytoplankton biomass. Data collected during the same cruise (Leblanc et al. 2002) suggested that the BSi accumulation could be the result of a bloom preceding the cruise period and/or an allochtonous input by lateral advection. Phytoplankton cell numbers were low and picoplankton was dominant, a general feature observed in different seasons in the Southern Ocean (Fiala et al. 2002). Picoplankton, nanoflagellates and coccolithophorids exceeded dinoflagellates and diatoms in numbers. This is consistent with data recorded during late summer to the south of Africa in the northern part of the PFZ (Kopczynska et al. 1986). In the PFZ, where temperature and salinity were comparatively low, $\mathrm{pCO}_{2}$ was close to equilibrium ( 360 $\mu \mathrm{atm})$. As phytoplankton biomass was low and the upper mixed layer was shallow (Sedwick et al. 2002), $\mathrm{pCO}_{2}$ was weakly influenced by biological activity or by a $\mathrm{CO}_{2}$ supply from deep water. Therefore, it was the air-sea $\mathrm{CO}_{2}$ exchange, enhanced by strong winds encountered in the region, that played an important role in $\mathrm{pCO}_{2}$ dynamics by maintaining $\mathrm{pCO}_{2}$ close to saturation.

Field experiments conducted during the cruise (Blain et al. 2002, Sedwick et al. 2002) indicated that dissolved iron availability was the primary limiting factor to nitrate drawdown and phytoplankton growth in the PFZ. On the other hand, low silicic acid availability exerted a secondary limitation on the diatom growth rate. Recent studies have shown that iron and/or silicate are limiting phytoplankton growth in different regions of the Southern Ocean (Sedwick et al. 1999, Boyd \& Law 2001, Hutchins et al. 2001).

The confluence of the SAF and STF reduced the SAZ to a very narrow band. The general trend of the merging SAF/STF front was southwest to northeast. The convergent front marked the transition between warm subtropical waters and cold subantarctic waters. A drastic drop in the nitrate values from southeast to northwest within the STF and in the STZ was ob- 
served, and suggested an active nutrient uptake by the preceding phytoplankton bloom reported about a month earlier from SeaWiFS images (Park et al. 2002). In the STZ surface waters, chl a concentrations increased slightly $\left(<0.4 \mu \mathrm{g} \mathrm{l}^{-1}\right)$, but remained lower than those observed during other seasons (Weeks \& Shillington 1996, Bradford-Grieve et al. 1997). Despite low concentrations, nitrates were not the main factor limiting primary production. As in the PFZ waters, dissolved iron availability associated with low orthosilicic acid concentrations limited phytoplankton growth (Sedwick et al. 2002). Low BSi concentrations reflected the low contribution of diatoms to phytoplankton biomass. Pico- and nano-size cells dominated the phytoplankton assemblage. Their distribution was patchy and the maximum counts (measured by flow cytometry analysis) of pico- and nanoplankton cells were $10^{7}$ and $5 \times$ $10^{6}$ cells $\mathrm{l}^{-1}$, respectively. Dominance of the small phytoplankton size fractions in the subtropical waters was also observed by Bradford-Grieve et al. (1997), Fouilland et al. (1999) and Froneman et al. (2001). Cyanobacteria dominated the pico-size fraction. Their distribution appeared to be mainly controlled by temperature, as they grew preferentially in warm $\left(>15^{\circ} \mathrm{C}\right)$ water masses where they constituted the dominant population. This is consistent with observations of Murphy \& Haugen (1985), who reported that decreases in cyanobacteria abundance correlate with decreasing temperature in the North Atlantic Ocean. The cyanobacteria abundance observed in the STZ was of the same order of magnitude as that reported for the North Atlantic (Murphy \& Haugen 1985, Veldhuis et al. 1993). The absence of prochlorophytes at the latitudes sampled was consistent with observations showing their disappearance at latitudes $>43^{\circ} \mathrm{S}$ (Fouilland et al. 1999). The STF is the scene of a dramatic northwards increase in cell quantities and species number of dinoflagellates. This change is probably attributable to an increase in water temperature which promotes the development of warm-water dinoflagellate species. Chl a concentrations were generally low within the STZ, but they increased to a maximum of $0.8 \mu \mathrm{g} \mathrm{l}^{-1}$ at the northeast border of the STF where the $\mathrm{AF}$ and the STF/SAF were in close proximity. This value, although high, was lower than values observed by Weeks \& Shillington (1996) and Read et al. (2000) in the Southwest Indian Ocean frontal region. The chl a peak is attributable to the development of diatoms and cyanobacteria. Peak chl a concentration and cell abundance were most probably due to the presence of a cyclonic eddy located northeast of the study grid which had recently detached from the SAF, as revealed by SeaWiFS images (Park et al. 2002). These images also showed that chl a concentrations were higher in the eddy edge than in the eddy core. This is consistent with previous studies conducted in the STF south of Africa (Dower \& Lucas 1993, Froneman et al. 1999).

Phytoplankton assemblages found in the Crozet Basin show similarities with regard to major groups and species composition to phytoplankton communities observed in late summer in the subantarctic region south of Africa (Kopczynska et al. 1986) and south of Australia (Kopczynska et al. 2001). In the present study and the 2 previous studies of Kopczynska et al. (1986, 2001), nanoflagellates and dinoflagellates increased both in cell densities and species numbers north of the PF towards the STZ. Diatoms were the least abundant group. Representatives of the genus Pseudonitzschia, dominant among diatoms in the Crozet Basin, have been previously reported to be typical north of the PF (Hasle 1969, Steyaert 1973, Kopczynska et al. 1986). Dinoflagellates were dominated everywhere by the nano-sized $(<20 \mu \mathrm{m})$ genera Gymnodinium, Gyrodinium and Prorocentrum. The highest differences in the species composition of this group were observed between the STZ of the Indian Ocean and south of Australia, and are attributable to the larger microsized $(>20 \mu \mathrm{m})$ species (Kopczynska et al. 2001). Also common to the present study and previous studies (Kopczynska et al. 1986, McKenzie \& Cox 1991, Kopczynska et al. 2001) is the observation that several species of diatoms (e.g. Nitzschia bicapitata, N. subpacifica, Thalassiothrix delicatula) and dinoflagellates (Ceratium pentagonum, C. lineatum, Oxytoxum spp.) were only encountered north of the PF. The rich flora of dinoflagellates and coccolithophorids found in the present study is typical of warm waters of the South Indian Ocean (Taylor 1976, Heimdal 1997).

Summer bacterial abundances $\left(0.5\right.$ to $2.5 \times 10^{6}$ cells $\mathrm{ml}^{-1}$ ) observed in the Crozet Basin were in a range of those (1.2 to $2 \times 10^{6}$ cells ml $^{-1}$ ) reported by Lochte et al. (1997) for the Atlantic sector of the PF during spring 1990, but were larger than abundances ( 0.2 to $0.5 \times$ $10^{6}$ cells ml$^{-1}$ ) recorded near the Kerguelen Islands during the 'Antares 3' cruise in October 1995 (M. Denis unpubl. data). Such differences could result from an uncoupling or time-lag between phytoplankton and bacterioplankton development. In line with this explanation, Billen \& Becquevort (1991) observed, in Prydz Bay and the Weddell Sea, a time-lag of about 15 to $30 \mathrm{~d}$ between the maxima of phytoplankton and bacterial biomasses. Similarly, bacterial numbers reached maximum values approximately 1 mo after blooms of Phaeocystis pouchetii in Antarctic coastal waters (Gibson et al. 1990, Davidson \& Marchant 1992).

Such an uncoupling can be explained in several ways, either by extremely low exudation of dissolved organic carbon, by phytoplankton, by low bacterial uptake or conversion of organic material, by repression of the bacterial metabolism due to low temperatures, or 
by high grazing pressure (Lochte et al. 1997). The present study was conducted during a post-bloom period in a region where phytoplankton growth is stimulated by the frontal hydrodynamics. This would explain the fact that bacterial concentrations were larger than those observed south of the Kerguelen Islands in January to March 1994 (0.1 to $0.6 \times 10^{6}$ cells ml ${ }^{-1}$, Talbot 1995) or south of Tasmania in February 1999 (2 to $4 \times 10^{5} \mathrm{cell} \mathrm{ml}^{-1}$, Hall \& Safi 2001).

The surface signatures of the fronts are clearly distinguishable in the pattern of $\mathrm{pCO}_{2}$. The distribution of $\mathrm{pCO}_{2}$ mirrored remarkably the meso-scale salinity distribution rather than temperature distribution. This was expected because in the PF area, cold and warm core eddy-like features show up more clearly in salinity than in temperature, as the latter is modified by atmospheric heat exchanges (Read et al. 2000). During the cruise, this phenomenon was likely to have been enhanced as a consequence of the narrowness of the frontal band. Furthermore, atmospheric heat exchange influences the $\mathrm{pCO}_{2}$ through the effect of temperature on thermodynamic equilibrium constants of the carbonate system. Taking into account the overall distribution of $\mathrm{pCO}_{2}$ during the cruise, atmospheric heat exchange enhanced the gradients of $\mathrm{pCO}_{2}$ at the fronts. As the northern warm and $\mathrm{CO}_{2}$-undersaturated waters approached the fronts, they tended to cool with a concomitant decrease in $\mathrm{pCO}_{2}$. On the other hand, the southern cold and slightly supersaturated waters tended to warm up and, conversely, $\mathrm{pCO}_{2}$ increased in the vicinity of the fronts. The large northwards drop in $\mathrm{pCO}_{2}$ is linked to the overall positive $\mathrm{S}-\mathrm{N}$ gradient of $\mathrm{chl}$ a. However, at the mesoscale, no significant drops in $\mathrm{pCO}_{2}$ were associated with the chl a maximum.

Furthermore, in the northeastern part of the survey area, the lowest $\mathrm{pCO}_{2}$ values were associated with both a minimum in nutrients concentration and a maximum in bacteria abundance, while chl a did not exhibit significant changes. The minimum concentration of nutrients and maximum number of bacteria were probably the consequence of a development of strong primary production prior to the cruise that led to the $\mathrm{pCO}_{2}$ minimum. Thereafter, the distribution of $\mathrm{pCO}_{2}$ generally appears to have reflected the impact of the bloom period preceding the cruise, indicating that the signature of the $\mathrm{CO}_{2}$ system distribution bloom remained for several weeks to months.

From the distribution of different biogeochemical parameters, the Crozet Basin frontal region appears to be a non-exporting system at the end of summer. This conclusion is particularly supported by the low contribution of large cells as well as the low contribution of siliceous organisms to the total phytoplankton. Biological activity was very low at that time of the year, as evidenced by the stronger dependence of $\mathrm{pCO}_{2}$ on hydrological structures. These results are also confirmed by the low primary production rates measured during the cruise (Leblanc et al. 2002). The present study period (January-February) marked the end of a productive period in that area, phytoplankton production being hindered by a combination of limiting resources including iron and silicic acid (Sedwick et al. 2002). Our results compare very well with the situation observed in the same season in the same sub-systems in the Australian sector, where phytoplankton were dominated by non-siliceous organisms (Kopczynska et al. 2001) and exhibited the same kind of limitation by iron and silicic acid (Sedwick et al. 1999, Quéguiner 2001).

Acknowledgements. This work is a French contribution to the SO-JGOFS program. It was supported by the French Polar Institute (IPEV) and the INSU-CNRS. This research was partly financed by the Polonium Program of scientific cooperation between Poland and France. It was also partly conducted under grants A4/DD/B14 and EV/12/7E within the Scientific Research on the Antarctic supported by the Belgian Office for Scientific, Technical and Cultural Affairs. We thank the captain, officers and crew of RV 'Marion Dufresne 2' and B. Ollivier for outstanding on board support. Special thanks to G. Grégori for stimulating discussions, Y. H. Park for constructive comments and C. Bangy for her help in running the flow cytometer. The comments of 2 anonymous reviewers greatly assisted in improving this manuscript.

\section{LITERATURE CITED}

Barange M, Pakhomov EA, Perissinotto R, Froneman PW, Verheye HM, Taunton-Clark J, Lucas MI (1998) Pelagic community structure of the Subtropical Convergence region south of Africa and in the mid-Atlantic Ocean. Deep-Sea Res Part I 45:1663-1687

Bathmann UV, Scharek R, Klaas C, Dubischar CD, Smetacek V (1997) Spring development of phytoplankton biomass and composition in major water masses of the Atlantic sector of the Southern Ocean. Deep-Sea Res Part II 44:51-67

Billen G, Becquevort S (1991) Phytoplankton-bacteria relationship in the Antarctic marine ecosystem. Polar Res 10: 245-253

Blain S, Tréguer P, Belviso S, Bucciarelli E and 8 others (2001) A biogeochemical study of the island mass effect in the context of the iron hypothesis: Kerguelen Islands, Southern Ocean. Deep-Sea Res Part I 48:163-187

Blain S, Sedwick PN, Griffiths FB, Quéguiner B, Bucciarelli E, Fiala M, Pondaven P, Tréguer P (2002) Quantification of algal iron requirements in the Subantarctic Southern Ocean (Indian sector). Deep-Sea Res Part II 49:3255-3273

Boyd PW, Law CS (2001) The Southern Ocean Iron Release Experiment (SOIREE) - introduction and summary. DeepSea Res Part II 48:2425-2438

Bradford-Grieve JM, Chang FH, Gall M, Pickmere S, Richards F (1997) Size-fractionated phytoplankton standing stocks and primary production during austral winter and spring 1993 in the Subtropical Convergence region near New Zealand. NZ J Mar Freshw Res 31:201-224

Bradford-Grieve JM, Boyd PW, Chang FH, Chiswell S and 5 others (1999) Pelagic ecosystem structure and functioning 
in the Subtropical Front region east of New Zealand in austral winter and spring 1993. J Plankton Res 21:405-428

Clementson LA, Parslow JS, Griffiths FB, Lyne VD and 6 others (1998) Controls on phytoplankton production in the Australasian sector of the subtropical convergence. DeepSea Res Part I 45:1627-1661

Copin-Montégut C (1988) A new formula for the effect of temperature on the partial pressure of carbon dioxide in seawater. Mar Chem 25:29-37

Copin-Montégut C (1989) A new formula for the effect of temperature on the partial pressure of carbon dioxide in seawater: Corrigendum. Mar Chem 27:143-144

Dafner EV, Mordasova NV (1994) Influence of biotic factors on the hydrochemical structure of surface water in the Polar Frontal Zone of the Atlantic Antarctic. Mar Chem 45: 137-148

Davidson AT, Marchant HJ (1992) Protist abundance and carbon concentration during a Phaeocystis-dominated bloom at an Antarctic coastal site. Polar Biol 12:387-395

Deacon GER (1982) Physical and biological zonation in the Southern Ocean. Deep-Sea Res 29:1-15

Dower KM, Lucas MI (1993) Photosynthesis-irradiance relationship and production associated with a warm-core ring shed from the Agulhas Retroflection south of Africa. Mar Ecol Prog Ser 95:141-154

El-Sayed SZ, Weber LH (1982) Spatial and temporal variations in phytoplankton biomass and primary productivity in the southwest Atlantic and Scotia Sea. Polar Biol 1: 83-90

Fiala M, Kopczynska EE, Jeandel C, Oriol L, Vetion G (1998a) Seasonal and interannual variability of size-fractionated phytoplankton biomass and community structure at station Kerfix, off the Kerguelen Islands, Antarctica. J Plankton Res 20:1341-1356

Fiala M, Semeneh M, Oriol L (1998b) Size-fractionated phytoplankton biomass and species composition in the Indian sector of the Southern Ocean during austral summer. J Mar Syst 17:179-194

Fiala M, Machado MC, Oriol L (2002) Phytoplankton distribution in the Indian sector of the Southern Ocean during spring. Deep-Sea Res Part II 49:1867-1880

Fouilland E, Descolas-Gros C, Courties C, Pons V (1999) Autotrophic carbon assimilation and biomass from size-fractionated phytoplankton in the surface waters across the subtropical frontal zone (Indian Ocean). Polar Biol 21:90-96

Frankignoulle M, Borges A, Biondo R (2001) A new design of equilibrator to monitor carbon dioxide in highly dynamic and turbid environments. Water Res 35:1344-1347

Franks PJS (1992) Phytoplankton blooms at fronts: patterns, scales, and physical forcing mechanisms. Rev Aquat Sci 6: 121-137

Froneman PW, McQuaid CD, Perissinotto R (1995) Biogeographic structure of microphytoplankton assemblages of the south Atlantic and Southern Ocean during austral summer. J Plankton Res 17:1791-1802

Froneman PW, McQuaid CD, Laubscher RK (1999) Size-fractionated primary production studies in the vicinity of the Subtropical Front and an adjacent warm-core eddy south of Africa in austral winter. J Plankton Res 21:2019-2035

Froneman PW, Laubscher RK, McQuaid CD (2001) Sizefractionated primary production in the south Atlantic and Atlantic sectors of the Southern Ocean. J Plankton Res 23: $611-622$

Furuya K, Hasumoto H, Nakai T, Nemoto T (1986) Phytoplankton in the Subtropical Convergence during the austral summer: community structure and growth activity. Deep-Sea Res 33:621-630
Gall M, Hawes I (1999) Predicting rates of primary production in the vicinity of the Subtropical Convergence east of New Zealand. NZ J Mar Freshw Res 33:443-455

Gamberoni L, Geronimi J, Jeanin PF, Murail JF (1982) Study of frontal zones in the Crozet-Kerguelen region. Oceanol Acta 6:289-299

Gibson JAE, Garrick RC, Burton HR (1990) Seasonal fluctuation of bacterial numbers near the Antarctic continent. Proc Natl Inst Polar Res (NIPR) Symp Polar Biol 3:16-22

Hall JA, Safi K (2001) The impact of in situ Fe fertilisation on the microbial food web in the Southern Ocean. Deep-Sea Res Part II 48:2591-2613

Hasle GR (1969) An analysis of the phytoplankton of the Pacific Southern Ocean; abundance, composition and distribution during the Bratteg Exp. 1947-48. Hvalråd Skr 52:1-168

Heimdal BR (1997) Modern coccolithophorids. In: Tomas CR (ed) Identifying marine phytoplankton, Academic Press, San Diego, p 731-831

Hense I, Bathmann UV, Timmermann R (2000) Plankton dynamics in frontal systems of the Southern Ocean. J Mar Syst 27:235-252

Hutchins DA, Sedwick PN, DiTullio GR, Boyd PW, Quéguiner B, Griffiths FB, Crossley AC (2001) Control of phytoplankton growth by iron and silicic acid availability in the Subantarctic Southern Ocean: experimental results from the SAZ project. J Geophys Res 106:31559-31572

Kopczynska EE, Weber LH, El-Sayed SZ (1986) Phytoplankton species composition and abundance in the Indian sector of the Antarctic Ocean. Polar Biol 6:161-169

Kopczynska EE, Dehairs F, Elskens M, Wright S (2001) Phytoplankton and microzooplankton variability between the Subtropical and Polar Fronts south of Australia: thriving under regenerative and new production in late summer. J Geophys Res 106:31597-31610

Laubscher, RK, Perissinotto R, McQuaid CD (1993) Phytoplankton production and biomass at frontal zones in the Atlantic sector of the Southern Ocean. Polar Biol 13: 471-481

Leblanc K, Quéguiner B, Fiala M, Blain S, Morvan J, Corvaisier R (2002) Particulate biogenic silica and carbon production rates and particulate matter distribution in the Indian sector of the Subantarctic Ocean. Deep-Sea Res Part II 49:3189-3206

Li WKW (1994) Primary production of prochlorophytes, cyanobacteria, and eukaryotic ultraphytoplankton: measurements from flow cytometric sorting. Limnol Oceanogr 39:169-175

Lochte K, Bjørnsen PK, Giesenhagen H, Weber A (1997) Bacterial standing stock and production and their relation to phytoplankton in the Southern Ocean. Deep-Sea Res Part II 44:321-340

McKenzie CH, Cox ER (1991) Spatial and seasonal changes in the species composition of armoured dinoflagellates in the Southwestern Atlantic Ocean. Polar Biol 11:139-144

Metzl N, Beauverger C, Brunet C, Goyet C, Poisson A (1991) Surface water carbon dioxide in the southwest Indian sector of the Southern Ocean: a highly variable $\mathrm{CO}_{2}$ source/ sink region in summer. Mar Chem 34:85-95

Metzl N, Louanchi F, Poisson A (1998) Seasonal and interannual variations of the sea surface carbon dioxide in the subtropical Indian Ocean. Mar Chem 60:131-146

Metzl N, Tilbrook B, Poisson A (1999) The annual $\mathrm{fCO}_{2}$ cycle and the air-sea $\mathrm{CO}_{2}$ flux in the sub-Antarctic Ocean. Tellus 51B:849-861

Murphy LS, Haugen EM (1985) The distribution and abundance of phototrophic ultraplankton in the North Atlantic. Limnol Oceanogr 30:47-58 
Nelson DM, Smith WO, Muench RD, Gordon LI, Sullivan CW, Husby DM (1989) Particulate matter and nutrient distributions in the ice-edge zone during late summer. Deep-Sea Res 36:191-209

Neveux J, Panouse M (1987) Spectrofluorometric determination of chlorophylls and pheophytins. Arch Hydrobiol 109: $567-581$

Nowlin WD Jr, Klinck JM (1986) The physics of the Antarctic Circumpolar Current. Rev Geophys 24:469-491

Paasche E (1973) Silicon and the ecology of marine plankton diatoms. I. Thalassiosira pseudonana (Cyclotella nana) grown in a chemostat with the silicate as limiting nutrient. Mar Biol 19:117-126

Pakhomov EA, Froneman PW (1999) The Prince Edward Islands pelagic ecosystem, south Indian Ocean: a review of achievements, 1976-1990. J Mar Syst 18:355-367

Pakhomov EA, McQuaid CD (1996) Distribution of surface zooplankton and seabirds across the Southern Ocean. Polar Biol 16:271-286

Park YH, Gamberoni L, Charriaud E (1991) Frontal structure and transport of the Antarctic Circumpolar Current in the South Indian sector, $40-80^{\circ}$ E. Mar Chem 35:45-62

Park YH, Gamberoni L, Charriaud E (1993) Frontal structure, water masses and circulation in the Crozet Basin. J Geophys Res 98:12361-12385

Park YH, Pollard RT, Read JF, Leboucher V (2002) A quasisynoptic view of the frontal circulation in the Crozet basin during the 'Antares-4' cruise. Deep-Sea Res Part II 49: 1823-1842

Perissinotto R, Laubscher RK, McQuaid CD (1992) Marine productivity enhancement around Bouvet and the South Sandwich Islands (Southern Ocean). Mar Ecol Prog Ser 88:41-53

Perissinotto R, Lutjeharms JRE, Ballegooyen van RC (2000) Biological-physical interactions and pelagic productivity at the Prince Edward Islands, Southern Ocean. J Mar Syst 24:327-341

Piola AR, Figueroa HA, Bianchi AA (1987) Some aspects of the surface circulation south of $20^{\circ} \mathrm{S}$ revealed by First Global GARP Experiment drifters. J Geophys Res 92: 5101-5114

Prieur L, Sournia A (1994) Processes and fluxes in the geostrophic Almeria-Oran front. J Mar Syst 5:187-203

Quéguiner B (2001) Biogenic silica production in the Australian sector of the Sub-Antarctic Zone of the Southern Ocean in late summer 1998. J Geophys Res 106: 31627-31637

Ragueneau O, Tréguer P (1994) Determination of biogenic silica in coastal waters: applicability and limits of the alkaline digestion method. Mar Chem 45:43-51

Read JF, Lucas MI, Holley SE, Pollard RT (2000) Phytoplank-

Editorial responsibility: Otto Kinne (Editor),

Oldendorf/Luhe, Germany ton, nutrients and hydrography in the frontal zone between the Southwest Indian Subtropical gyre and the Southern Ocean. Deep-Sea Res Part I 47:2341-2368

Roberts PE (1980) Surface distribution of albacore tuna, Thunnus alalunga Bonaterre, in relation to the Subtropical Convergence Zone east of New Zealand. NZ J Mar Freshw Res 14:373-380

Sedwick PN, Ditullio GR, Hutchins DA, Boyd PW, Griffiths FB, Crossley AC, Trull TW, Quéguiner B (1999) Limitation of algal production by iron and silicic acid deficiency in the Australian Subantarctic region. Geophys Res Lett 26: 2865-2868

Sedwick PN, Blain S, Quéguiner B, Griffiths FB, Fiala M, Bucciarelli E, Denis M (2002) Chemical limitation on phytoplankton growth in the Crozet Basin, Subantarctic Southern Ocean. Deep-Sea Res Part II 49:3327-3349

Smith WO Jr, Nelson DN (1990) Phytoplankton growth and new production in the Weddell Sea marginal ice zone in the austral spring and autumn. Limnol Oceanogr 35: 809-821

Steyaert J (1973) Distribution of plankton diatoms along an African-Antarctic transect. Invest Pesq (Barc) 37:295-328

Sullivan CW, Arrigo KR, McClain CR, Comiso JC, Firestone J (1993) Distributions of phytoplankton blooms in the Southern Ocean. Science 262:1382-1387

Talbot V (1995) Activité protéolytique et dynamique bactérienne en Océan Austral. Thesis, Université Aix-Marseille II

Taylor FJR (1976) Dinoflagellates from the international Indian Ocean expedition. Bibl Bot 132:1-234

Tréguer P, Le Corre P (1975) Manuel d'analyses des sels nutritifs dans l'eau de mer. Utilisation de l'AutoAnalyzer II. Document Université de Bretagne Occidentale, Brest

Trousselier M, Courties C, Zettlemaier S (1995) Flow cytometric analysis of coastal lagoon bacterioplankton and picoplankton: fixation and storage effects. Estuar Coast Shelf Sci 40:621-623

Utermöhl H (1958) Zur Vervollkommnung der quantitativen Phytoplankton-Methodik. Mitt Int Ver Theor Angew Limnol 9:1-38

Van Ballegooyen RC, Grundlingh Ml, Lutjeharms JRE (1994) Eddy fluxes of heat and salt from the southwest Indian Ocean into the southeast Atlantic Ocean: a case study. J Geophys Res 99:14053-14070

Veldhuis MJW, Kraay GW, Gieskes WWC (1993) Growth and fluorescence characteristics of ultraplankton on a northsouth transect in the eastern North Atlantic. Deep-Sea Res Part II 40:609-626

Weeks SJ, Shillington FA (1996) Phytoplankton pigment distribution and frontal structure in the subtropical convergence region south of Africa. Deep-Sea Res Part I 43:739-768

Submitted: February 4, 2002; Accepted: September 26, 2002 Proofs received from author(s): February 13, 2003 